\title{
De persoon tussen wal en schip
}

\author{
A.W.M. Mooij*
}

\section{Het forensisch-psychiatrische veld}

Het forensisch-psychiatrische veld bevindt zich op een kruispunt van juridische kaders en een diversiteit aan zorg- en behandelvoorzieningen. De juridische kaders worden gevormd door het strafrecht en wat vroeger het krankzinnigenrecht heette en thans het BOPZ-recht wordt genoemd, met maatregelen als terbeschikkingstelling (TBS) met of zonder bevel tot verpleging, in haar verschillende fasen van de tenuitvoerlegging (proefverlof), en het opleggen van een bijzondere voorwaarde bij een voorwaardelijk strafdeel, inbewaringstelling (IBS), rechterlijke machtiging (RM) enz. Wat de voorzieningen betreft kennen wij de traditionele psychiatrische ziekenhuizen (APZ), met hun gesloten of niet-gesloten afdelingen en eventueel een afdeling voor sterk gedrags- en agressiegestoorden (SGA), of een forensisch-psychiatrische kliniek (FPK). Daarnaast zijn er de bekende TBS-klinieken en bijzondere instellingen als de kliniek voor Forensische Psychotherapie 'Groot Batelaar'.

Er lijkt zo een fijnmazig net te bestaan van voorzieningen en kaders, maar tevens blijkt dat er tal van gevallen zijn die niet in aanmerking komen voor één van beide types voorzieningen, of zich niet lenen voor interventie vanuit een der juridische kaders. Ook kan blijken dat iemand bijvoorbeeld wel geschikt is voor een bepaald type van voorziening, maar dat het juridische kader niet toereikend is. Zo valt men dus tussen kade(r) en schip.

*Zenuwarts, bijzonder hoogleraar forensische psychiatrie RU Groningen en hoogleraar forensische psychiatrie Universiteit Utrecht. 


\section{Persoons- en omgevingsfactoren}

Er zijn twee typen van factoren die uitmaken of een persoon tussen wal en schip valt. Enerzijds zijn er factoren die verbonden zijn met de persoon, anderzijds zijn er omgevingsfactoren (met betrekking tot de diverse juridische kaders en de specifieke aard van de diverse behandel- en zorginstellingen). Hoewel uiteraard juist het niet afgestemd zijn van omgevingsfactoren op persoonsgebonden factoren de 'val' veroorzaakt, zal ik mij in mijn bijdrage eerst richten op de persoonsgebonden factoren, en pas van daaruit een overstap maken naar de omgevingsfactor van kader en voorziening.

Het spreekt welhaast vanzelf dat hierbij geen aandacht gevraagd wordt voor situaties waarbij het grensverkeer juist soepel verloopt of waar dit relatief weinig consequenties heeft, zoals bijvoorbeeld de overplaatsing van een psychisch gestoorde gedetineerde naar een psychiatrisch ziekenhuis in de fase van de preventieve hechtenis of in de executiefase volgens art. 47/120 Gevangenismaatregel. Ook al zou de indruk van het tegendeel rijzen, het is natuurlijk niet allemaal kommer en kwel.

Klemmend wordt het wel, als iets spaak loopt en bovendien de gevolgen ingrijpend zijn, zoals bij het al dan niet opleggen van een rechterlijke machtiging, van een terbeschikkingstelling of het al dan niet beëindigen daarvan.

\section{Drie voorbeelden}

Een aantal klemmende situaties kan door de volgende voorbeelden geïllustreerd worden.

1.Een jongeman, verdacht van een niet zeer ernstig delict (bedreiging met geweld) werd aangemeld bij een behandelkliniek. Hoewel zijn intelligentie toereikend was voor het type van behandeling dat daar geboden wordt en hij zeer gemotiveerd was voor zulk een behandeling en ook subjectief leed, werd hij niet als patiënt geaccepteerd omdat de kliniek vreesde dat hij zich aan een behandeling zou kunnen gaan onttrekken, wanneer aan gevoelige punten geraakt zou worden. In het kader van een later gedragskundig onderzoek naar aanleiding van eenzelfde soort van strafbaar feit werd een terbeschikkingstelling geadviseerd (dat gebaseerd was op de verwachting van een toenemende escalatie van geweld). Hier werd de middelzware optie van een klinische behandeling in het kader van een bijzondere voorwaarde bij een voorwaardelijk strafdeel verworpen ten gunste van de zwaarste sanctie-modaliteit. 
2.Een tweede voorbeeld betreft een oudere man die tal van periodes van ontremd zijn meemaakte en in verband daarmee ook vele malen opgenomen was geweest in het kader van een inbewaringstelling dan wel rechterlijke machtiging, welke bijna steeds vroegtijdig werden beëindigd. Naar aanleiding van een matig ernstig geweldsdelict werd de betrokkene onderzocht en werd de mogelijkheid van een behandeling in het kader van een bijzondere voorwaarde verworpen wegens gebrekkig ziekte-inzicht, gebrekkige motivatie tot gedragsverandering en werd met het oog op het recidive-risico, ook hier weer, een terbeschikkingstelling geadviseerd. Hierbij werd weliswaar de kanttekening gemaakt dat de doelstelling hiervan beperkt zou dienen te zijn en dat de behandeling zich vooral zou moeten richten op goede medicatie-instelling en op motivering tot acceptatie van een blijvende handicap. Kern van deze casus is de ontoereikendheid van de rechterlijke machtiging bij dit type van stoornis.

3.Een derde en laatste voorbeeld betreft de problematiek die zich voordoet bij de beëindiging van een lopende terbeschikkingstelling. Het ging om een chronisch psychotische man die al vele jaren in het kader van een terbeschikkingstelling werd verpleegd en slechts een geringe medicatietrouw vertoonde. Op grond van het voortdurende gevaar voor personen, op een langere termijn en in een slechts algemene zin, werd toch, min of meer tegen de zin van alle betrokkenen in, de terbeschikkingstelling steeds opnieuw verlengd.

De drie voorbeelden zullen als type vertrouwd overkomen, maar zij maken ook duidelijk waarom er zulke grote capaciteitsproblemen in het veld van de terbeschikkingstelling heersen. Wie tussen de wal en het schip valt, komt tenslotte in de trechter van de terbeschikkingstelling terecht, waarvan de uitgang erg nauw is, zodat die trechter snel dreigt over te lopen. Dit leidt tot het bekende actuele capaciteitstekort in het TBS-veld. Voordat wij op dit punt in kunnen gaan is het nodig, ook in het licht van onze taak, meer zicht te krijgen op de persoonsgebonden factoren die hier spelen. 


\section{Persoonsgebonden factoren: drie soorten beperkingen}

De persoonsgebonden beperkingen kunnen zich manifesteren op het vlak van wat iemand kan, waartoe hij in staat is, respectievelijk wat hij niet kan en waartoe hij niet in staat is. De beperkingen kunnen daarnaast betrekking hebben op wat iemand wil, respectievelijk niet wil. Het handelen van een persoon veronderstelt immers bepaalde capaciteiten, vermogens en de wil om te handelen. Een derde categorie van beperkingen betreft de combinatie van beide beperkingen, ten aanzien van het kunnen en het willen gezamenlijk.

Bij de eerste soort beperking is de betrokken persoon 'onvermogend', kan hij iets niet of niet voldoende (of men vindt dat hij 'het' niet kan). Waar het om gaat is de taxatie van de introspectieve vermogens, de emotionele toegankelijkheid van de problematiek, de bereikbaarheid daarvan. Bij dit type van factoren hoort ook het recidive-risico, de gevaarlijkheid, te weten het vermogen tot gevaarlijk gedrag, respectievelijk het onvermogen dit gevaarlijke gedrag in het algemeen of in bepaalde situaties achterwege te laten.

De tweede soort van beperkingen betreft het willen. De persoon in kwestie wil dan geen behandeling, aarzelt, óf wil het naar het inzicht van de onderzoeker onvoldoende; of de onderzoeker aarzelt of de onderzochte de behandeling in voldoende mate wil. Het gaat hierbij niet primair om de vraag of er sprake is van een wilsstoornis, bijvoorbeeld wilszwakte, maar om een taxatie van de duurzaamheid van iemands eventuele wil met betrekking tot een behandeling. Hierbij kunnen allerlei factoren een rol spelen, zoals slechte ervaringen in het verleden met psychiatrische bemoeienis, begrijpelijke angst voor verandering en tenslotte angsten die samenhangen met de stoornis. Deze factoren hebben dan als gevolg dat iemands wil terzake als onvoldoende wordt getaxeerd, of dat de onderzoeker onvoldoende zeker is of die wil in voldoende mate aanwezig is, wat op hetzelfde neerkomt.

Uiteraard is de uiteindelijke grens tussen de beperkingen in de vermogenssfeer en in de wilssfeer niet scherp. Een beperkte wil kan wijzen in de richting van gebrekkig ziekte-inzicht en dat is een bepaald onvermogen. En een gebrekkig introspectief vermogen heeft soms weer te maken, ten dele, met een onwil deze problematiek onder ogen te zien. Daarom komen beide soorten van beperkingen - waarvan het onderscheid tot nu toe nuttig is gebleken - gelijktijdig voor. Dit is een derde soort van beperking: het gelijktijdig voorkomen van de eerste twee. Men denkt hierbij aan een belangrijke categorie, die daarom ook apart opgevoerd mag worden, van personen bij wie er geen of weinig bereidheid is een behandeling te ondergaan blijkend uit medicatie-on- 
trouw- terwijl de gevaarlijkheid zodanig is dat het vrije verkeer in de samenleving risico's met zich meedraagt.

\section{Persoonlijke beperkingen en begrenzende kaders}

Hierboven hebben wij al gememoreerd dat tussen-wal-en-schipsituaties zich vooral voordoen wanneer persoonlijke beperkingen gerelateerd worden aan de begrenzing die een juridisch kader of een bepaalde behandel- of zorginstelling impliceert. Het spreekt vanzelf dat de verschillende soorten van beperkingen zich kunnen doen gelden op ieder van de gesignaleerde beslismomenten: de afweging met betrekking tot het opleggen van een bijzondere voorwaarde bij een voorwaardelijk strafdeel, het opleggen van een rechterlijke machtiging en het beëindigen van een terbeschikkingstelling. Toch is er ook een zekere specifiteit.

Bij een bijzondere voorwaarde gaat het vooral om de vraag of iemand voldoende wil. Cruciaal is hierbij de vraag naar de bereidheid zich in behandeling te begeven, zowel feitelijk als emotioneel. Thans is het alternatief een terbeschikkingstelling. Bij twijfel is men geneigd op 'safe' te spelen en zich uit te spreken voor een terbeschikkingstelling (waarbij nog komt dat de bijzondere voorwaarde niet in aanmerking komt bij ernstige feiten in verband met de hierbij geldende straflimiet).

Bij een rechterlijke machtiging speelt daarentegen de taxatie van de wilsfactoren slechts een beperkte rol. De betrokkene wil -uiteindelijk- immers niet opgenomen worden, anders was er geen sprake van een gedwongen opneming. Bij de vraag naar de noodzaak van eventuele gedwongen opneming spelen derhalve vooral overwegingen aangaande de vermogenssfeer: hoe gevaarlijk is de persoon?

Het probleem is hierbij, zoals genoegzaam bekend, de 'bandbreedte' van het begrip 'gevaarlijkheid'. Een eng opgevat gevaarscriterium blokkeert het afgeven van een rechterlijke machtiging en bespoedigt bovendien het beëindigen ervan. Zulks leidt weer tot de bekende draaideur-psychiatrie - wat voorbeeld 2 illustreerde - aan het eind waarvan, soms na een meer of minder ernstig delict, een terbeschikkingstelling volgt.

De combinaties van beperkingen in de vermogenssfeer en de wilssfeer, tenslotte treffen wij nogal eens aan als specifiek overwegingspunt bij de vraag of een terbeschikkingstelling, die nu al jaren heeft geduurd, beëindigd mag worden of niet. Er is dan een zekere rest-gevaarlijkheid, omdat de stoornis niet afdoende behandeld kon worden, of van zichzelf niet voldoende behandelbaar 
is, terwijl de bereidheid om zich aan een toezicht te onderwerpen gering is en een proefverlofsituatie die uitzicht biedt op een ongeclausuleerde terugkeer in de samenleving ook niet reëel is.

\section{Nuancering juridische kaders}

Om aan dit soort problemen die deels voortvloeien uit persoonsgebonden beperkingen, het hoofd te kunnen bieden, is het te overwegen in de begrenzingen die de juridische kaders stellen wat meer nuance aan te brengen. Dit is overigens ook al bij herhaling bepleit, met name vanuit de Commissie Fokkens. Het zou neer kunnen komen op de volgende specificaties.

De herinvoering van de voorwaardelijke terbeschikkingstelling zou het scala aan mogelijkheden aanzienlijk verruimen, als een tussenvoorstel tussen een behandeling in het kader van een bijzondere voorwaarde en een terbeschikkingstelling met bevel tot verpleging.

Bij de problematiek van de gedwongen opneming zou men, zoals ook al gebruikelijk wordt, minder kunnen koersen op een eng geïnterpreteerd gevaarscriterium. Met betrekking tot de beëindiging van de terbeschikkingstelling is het zinvol de voorwaardelijke beëindiging in te voeren, zodat men in het grijze tussengebied van wel of niet verlengen op een tussenpositie kan terugvallen.

Een praktisch voordeel van deze courante voorstellen is dat, bij effectuering daarvan, de druk op het TBS-veld zal afnemen. Aan de toename van 'voorwaardelijke constructies' kleven echter ook bezwaren, omdat de rechtsbescherming in zulke verbanden vaak moeilijk is vorm te geven en men in de praktijk spoedig tot een gemakkelijke paternalistische aanpak kan vervallen. Dit geldt ook voor de verruiming van het gevaarscriterium, dat dan in de buurt komt van het bestwil-criterium, met een daaraan inherente roep om meer dwang die wij nu ook luide horen. Daar staat dan weer tegenover dat bij constructies als deze -en dat geldt in het bijzonder voor 'voorwaardelijke constructies' - uiteindelijk een groter appèl op de eigen verantwoordelijkheid gedaan wordt, en de betrokkenen nadrukkelijker worden uitgenodigd er wat van te maken.

Goede, bevredigende oplossingen zijn dit al met al uiteindelijk ook niet. Het mag duidelijk zijn dat pogingen oplossingen te vinden voor mensen die tussen wal en schip dreigen te vallen, per definitie haast een compromis-karakter hebben en op deze manier 'wat van het één' en 'wat van het ander' hebben en 
daarmee ook iets onbevredigends houden. Dat is echter een vertrouwde situatie op het gebied van psychiatrie en recht.

Een belangrijk voordeel is dat deze voorstellen voortbouwen op bestaande regelingen die slechts aangevuld of gemodificeerd behoeven te worden. Het belang daarvan is niet slechts pragmatisch maar ook principieel. Het traditionele stelsel noodzaakt immers tot de voortdurende afweging of een psychiatrische interventie per se noodzakelijk is om een gevaar - afgezien van de nadere bepaling daarvan - af te weren of niet. Indien zulks niet het geval is, is interventie juridisch niet gerechtvaardigd. Het gangbare stelsel beperkt dus de omvang van meer of minder afgedwongen of afdwingbare psychiatrische bemoeienis, waarachter de veronderstelling ligt dat psychiatrische bemoeienis een sterke ingreep impliceert in de intieme levenssfeer waarmee men behoedzaam dient om te gaan. Het gevolg daarvan is onvermijdelijk het optreden van klemsituaties, zoals er hiervan enkele zijn benoemd. Er gaat van deze klemsituaties een verleiding uit om dan maar het gehele stelsel over boord te zetten en een veel intensievere psychiatrische bemoeienis met justitiabelen te bepleiten.

Waar de goede bedoelingen echter zo op de voorgrond staan, zal de vraag naar de legitimatie van psychiatrische interventies naar de achtergrond verdwijnen. De vraag welke mate, welke aard, welk type van indringendheid van psychiatrische zorg aangeboden en uiteindelijk afgedwongen mag worden, is in dat geval niet meer de leidende vraag. De beschermende taak van het recht plaatst deze vraag echter juist op de voorgrond. Precies vanwege het centrale karakter van deze vraag is het te verkiezen knelpunten, die van deze stand van zaken een uitvloeisel zijn, te verzachten, in plaats van de komen tot een omvattende stelselwijziging waarin voor deze beschermende vraag weinig ruimte meer is. 